\title{
The Use of Learning Community Incorporating with Lesson Study in Teaching and Learning Mathematics through TPACK and SAMR Model: The Effects on Students' Mathematics Achievement
}

\author{
Lilla Adulyasas* \\ Yala Rajabhat University, Thailand \\ *lilla.a@yru.ac.th
}

\begin{abstract}
The challenge of $21^{\text {st }}$ century education in technological era is to develop effective tools for teaching and learning. This research aimed to (i) use learning community incorporating with lesson study for developing patterns in integrated teaching of mathematics with the use of technology based on TPACK and SAMR Model and determine pre-service teachers' levels of technology integration in their teaching, (ii) examine the effects of the integrated teaching on students' achievement, (iii) determine students' learning retention, and (iv) measure students' level of satisfaction towards learning. Participants included four pre-service teachers in mathematics education program, Yala Rajabhat University, Thailand who had teaching practicum in 2018 academic year. Samples are 117 secondary students of four intact classes at Satree Yala School whom were selected by purposive sampling based on teaching responsibilities of the four pre-service teachers. The researcher employed quasi-experimental research design for conducting this study. Content analysis was used to examine levels of technology integration among the pre-service teachers while pair sample t-test was used to determine students' achievement and their learning retention. Moreover, descriptive statistics were used to find their level of satisfaction towards learning. Finding revealed that the pre-service teachers utilized technology in their teaching based on the concept of TPACK with a level four of technology integration in SAMR Model which is the highest level. Moreover, the students' posttest mean scores were significantly greater than pretest at the significant level of 0.05 in all target contents, the students had learning retention, and showed their satisfaction towards learning.
\end{abstract}

Keywords

Learning community, Lesson study, Mathematics, SAMR Model, TPACK

\section{Introduction}

Teaching and learning of mathematics today have been encountering a great deal of issues. One of a number of causes is that the use of teacher-centered teaching approach which focuses mainly on conveying of content knowledge rather than thinking stimulation. For this reason, students have learnt mathematics with a lack of understanding. Also, some contents in mathematics are more on abstract concepts so that it is challenging for them to have a full comprehension. Some teachers use their familiar teaching methods and are unable to equip tools and teaching materials in classroom. Additionally, they are unproductive in innovating teaching materials or implementing the modern teaching methods (Niess, 2006). Therefore, the main challenge in the $21^{\text {st }}$ century education is to search and develop effective tools that can promote meaningful teaching and learning of mathematics. These days, it is widely accepted that technology has played powerful roles in different aspects in our life. With an increase in innovative technology in education, it is not surprising that technology can bring great changes to education, and that provides learners with tremendous learning opportunities. Importantly, technology also enhances teacher's belief in teaching and learning and their teaching approaches and practices (Erdogan \& Sahin, 2010). The use of technology in teaching and learning shows positive effects on learners' achievement as technology considers as an intelligent tool enabling an efficient connection between teaching approaches and important contents in mathematics. Jimoyiannis (2010) and Srisawasdi (2012) point out that technology not only facilitates teachers' teaching, but also supports students' learning process. For this reason, it is important for teachers to learn and improve skills in designing lessons with technology integration and to use technology integrated lessons in assisting learners to achieve successful learning goals in curriculum (Kimberly, Lawless, \& Pellegrino, 2007).

Mishra and Koehler (2006) developed theoretical framework of Technological Pedagogical Content Knowledge or TPACK which was defined as teacher's knowledge in teaching a particular content with technology. This premise includes three aspects; (i) Technological Knowledge, (ii) Pedagogical Knowledge, and (iii) Content Knowledge which are typically implemented for promoting effective teaching and learning through technology integration. TPACK as shown in Figure 1 is described as a foundation of success in teaching and learning which is relevant to the use of technology in the way that encourages knowledge and understanding of concepts by organizing and conveying creative teaching and learning in diverse contents (Mishra \& Koehler, 2009). As a matter of fact, it is imperative for teachers to have knowledge and understanding of integrating the three aspects in TPACK. 


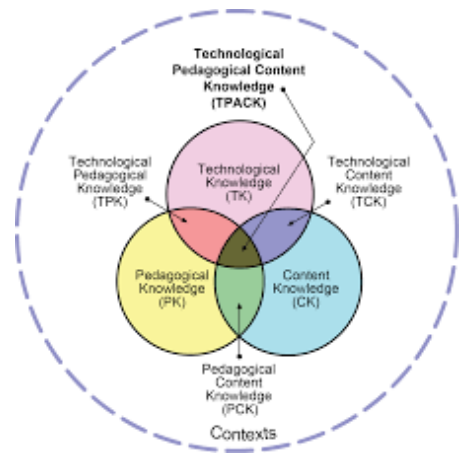

Figure 1. Theoretical framework of TPACK (Mishra \& Koehler, 2006)

Apart from that, Ruben Puentedura evolved and proposed SAMR Model which is used to explain levels of technology integration in teaching and learning for two dimensions, that is, enhancement and transformation. The technology integration underlying SAMR Model can be divided into four levels including (i) Level One: S-Substitution which refers the use of technology for compensating the old tools, (ii) Level Two: A-Augmentation which means the use of technology for improving an effectiveness of the current tools, (iii) Level Three: M-Modification concerns the use of technology for increasing an effective teaching which leads to a design of new teaching and learning, and (iv) Level Four: R-Redefinition is the use of technology for creating new fruitful learning opportunities and new different teaching methods (Puentedura, 2015). SAMR Model in Figure 2 is, therefore, useful for indicating the levels of effectiveness in technology integration in teaching and learning management.

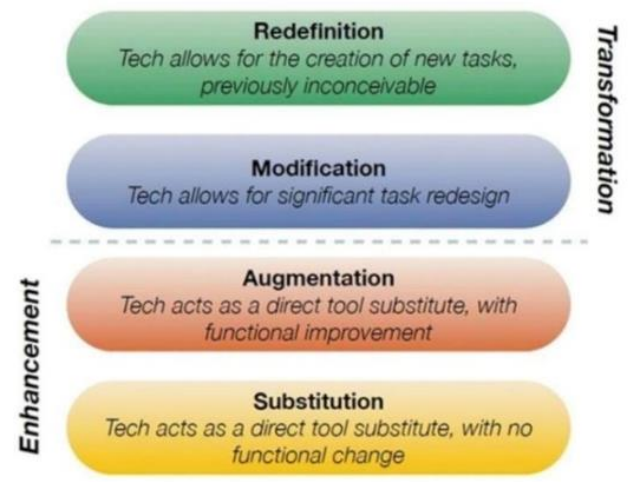

Figure 2. SAMR model (Puentedura, 2015)

No matter how important an integration of technology in teaching and learning is; however, a number of teachers who is willing to use technology is scant so far. Different causes are lack of expertise in technology integration, worries about time constrain, and self-reliance on their teaching performance (Norton, McRobbie, \& Cooper, 2000; Pelgrum, 2001; Shamburg, 2004). These factors prevent students from accomplishment in their mathematics learning which has been evident in their achievement. The researcher carried out the study examining mathematics teachers' TPACK in three southernmost provinces Thailand and the results reported that the teacher participants showed their abilities in TPACK at a medium level (Adulyasas, 2017). As such, this is presumed that the teacher participants had not been fostered to integrate technology in teaching and learning when they studied first degree in teaching program. An interesting fact is that pre-service teachers who have been encouraged to use technology during their studies tend to engross with the use of technology in their teaching and involve in learning of how to integrate technology to teach a specific content of knowledge. Hence, the universities which offer teaching programs should pay attention to mission in promoting the use of technology for integrating with teaching methods in teaching some contents in curriculums, especially those courses relating to abstract concepts. Several different contents in mathematics link with the abstract concepts so that the support of technology integration is beneficial for presenting those concepts in a more concrete manner.

In addition to technology integration, one potential practice in preparing a readiness for pre-service teachers is to consider "Learning Community". The important process in gathering a group of individuals in learning community is to create a platform for exchanging knowledge about general academic interests and sharing goals in teaching and learning together. The advantages of learning community include development of knowledge, skills, and attitudes of members through exchanging, participatory learning, and supporting from other members (Chang, Wang, \& Feng, 2010). Members in one learning community typically share issues or needs on topics that they together engage in order to figure out better way for development. Chang, Hsu, and Ciou (2017) articulated that learning community is useful for constituting readiness in preparing pre-service teachers before they take a role as an in-service teacher in schools. Besides that, learning community could support teacher's learning, prevent an isolation from their professional development, create inspiration in conceptualizing new concepts as well as improve abilities in connecting theories with practices. Also, their experiences with learning community enable pre-service teachers to apply them in their teaching profession (Dinmore \& Wenger, 2006). In addition, incorporating learning community with the notion of "Lesson Study" which mainly concerns a process in developing teaching profession with cooperative teaching in different steps such as planning of lessons, classroom observing, and reflecting teaching practice can advocate development of teaching and learning as well. This idea intends to support great learning experiences for learners, to develop teacher's teaching profession, and to promote teacher's more effective teaching practice (Inprasitha, 2010).

In the present study, the researcher employed learning community incorporating with lesson study using the two conceptual frameworks which affect teaching in the $21^{\text {st }}$ century education to develop integrated teaching of mathematics based on TPACK and SAMR Model. With the development of the integrated teaching, the focuses in this research were to examine the pre-service teachers' levels of technology integration, to determine the students' mathematics achievement and their learning retention, and to measure the students' levels of satisfaction towards learning. The completion of the present study would uplift teaching of mathematics with technology integration and enhance students' achievement in mathematics which in turn contribute to more effective teaching of mathematics and positive significant impacts on learners in long-run. 


\section{Research Method}

\section{Materials and Methods}

This study employed mix-method research design using qualitative research method for examining pre-service teachers' levels of technology integration while a quasiexperimental research design which applied one-group pretest-posttest design was used for determining students' mathematics achievement. After two weeks of the intervention period, delay posttest was administered to the students to determine their learning retention and questionnaire was used for measuring the students' level of satisfaction towards learning.

\section{Research Participants}

The participants were four female pre-service teachers in mathematics education program of Yala Rajabhat University, Yala, Thailand. As the requirement in the program, they had teaching practicum in 2018 academic year at Satree Yala School, Muang district, Yala. They were under the researcher's supervision and they had an interest in integrating technology to organize teaching and learning in the assigned contents in the school.

\section{Samples}

The samples were 117 secondary school students in four intact classes of Satree Yala School whom were selected with purposive sampling technique based on the different contents taught by the four pre-service teachers. Details of the samples are follows:

Group One were 30 seventh-grade students learning in linear equation of one variable.

Group Two were 32 seventh-grade students learning in ratio.

Group Three were 28 eleventh-grade students learning in frequency distribution with graph.

Group Four were 27 eleventh-grade students learning in absolute value of complex number and complex number in polar form.

\section{Research Instruments}

1) The four pre-service teachers' lesson plans for integrated teaching based on the concepts of TPACK and SAMR Model in the target contents that the pre-service teachers were responsible for teaching in the school included linear equation of one variable and ratio for seventh graders as well as frequency distribution with graph and absolute value of complex number and complex number in polar form for eleventh graders. The lesson plans with different contents designed by the four pre-service teachers were based on group discussion in learning community and lesson study process. Those lesson plans were checked with content validity by experts and some amendments were made based on the experts' suggestions.

2) A set of questions posted by the researcher in learning community with the concept of lesson study to create a platform for exchanging, reflecting, and discussing among the pre-service teachers on teaching and learning with technology integration based on TPACK and SAMR Model. The questions were sent to the experts for content validity checking and improved accordingly based on their feedback. The main points of views under the questions discussed in learning community included (i) reflecting on problems and identifying learning objectives of the responsible contents, (ii) analyzing causes of the problems in teaching and discussing of how technology can support effective teaching on those contents, (iii) searching directions of how to design lessons with appropriate technology integration for teaching the different contents to serve learning goals, (iv) reflecting how the use of selected technology can assist students' learning after the implementation of lesson plans in each content, and (v) deciding about a suitability of technology integration in teaching and learning as specified in the lesson plans and discussing on how to improve their teaching for students' better understanding in each content.

3) Multiple choice mathematics achievement pretest and posttest of each content included 20 items in linear equation of one variable and 20 items in ratio for seventh graders, and 15 items in frequency distribution with graph and 20 items in absolute value of complex number and complex number in polar form for eleventh graders were used to collect quantitative data. All achievement tests were verified by the experts to determine their content validity and found that all items in each set of tests were congruent with their objectives as determined by IOC with an indication of 1.00 . Then the tests were used for pilot testing to examine reliability, level of difficulty, and power of discrimination. The Cronbach's alpha value of reliability for the tests on linear equation of one variable, ratio, frequency distribution with graph, and absolute value of complex number and complex number in polar form was $0.83,0.89,0.84$, and, 0.94 respectively. The different sets of tests showed levels of difficulty with a range of $0.26-0.59$ and had power discrimination of above 0.45 .

4) A questionnaire on the students' satisfaction towards learning with the integrated teaching was also checked its content validity by the experts. Then, it was tried out in the pilot study conducted before actual data collection and reported the Cronbach alpha's value at 0.91 .

\section{Data Collection}

The researcher as an advisor of the four pre-service teachers made appointments for conducting this research which took place once a week throughout the second semester of the 2018 academic year or based on their convenient time either at the university or the school. The researcher used the process in learning community incorporating with lesson study using the prepared questions for group discussion. In this procedure, the pre-service teachers reflected problems in their teaching in order to design their lesson plans together. Then, they observed other's classes to reflect their opinions on their friend's teaching and provide comments and directions for improving the teaching and suggesting the way to use technology which aimed to facilitate effective teaching and to achieve learning objectives. Prior to the use of the integrated teaching, the students in each group took pretest for measuring their mathematics achievement. Then, the four pre-service teachers employed the lesson plans which integrated with the use of technology based on TPACK and SAMR Model in their classes. After that, the students were given posttest for measuring their achievement after they studied with the integrated teaching while the questionnaire on satisfaction towards learning was administered to the students. Two weeks after the intervention, the students were measured their achievement 
again with delay posttest for examining their learning retention.

\section{Methods of Data Analysis}

The researcher used content analysis to analyze qualitative data for determining levels of technology integration in teaching based on SAMR Model (Puentedura, 2015). The levels used to access the four pre-service teacher participants are as follows:

Level One: S-Substitution is used to indicate when they use technology to compensate the previous tool.

Level Two: A-Augmentation is used to indicate when they use technology to improve an effectiveness of the current tool.

Level Three: M-Modification is used to indicate when they use technology to enhance an effectiveness which leads to design of new teaching with suitable technology.

Level Four: R-Redefinition is used to indicate when they use technology to create new learning opportunities and new teaching which is different from the previous ones.

For quantitative data analysis, the researcher used pair sample t-test to determine the students' mathematics achievement and their learning retention. Furthermore, descriptive statistics (i.e., mean and standard deviation) was used to find the students' levels of satisfaction towards learning with the integrated teaching. Criteria for justifying the students' mean score on their satisfaction can be classified in five levels; least satisfactory (1.00-1.80), less satisfactory (1.81-2.60), medium satisfactory (2.61-3.40), much satisfactory (3.41-4.20), and most satisfactory (4.21$5.00)$.

\section{Results}

\section{Part One (Qualitative results)}

Pre-service teachers' levels of technology integration used in their teaching of mathematics based on TPACK and SAMR Model which resulted from the use of learning community incorporating with lesson study.

After the four pre-service teacher participants attended in learning community integrating with lesson study process, they implemented the concepts of TPACK and SAMR Model in organizing teaching and learning of mathematics with the contents on linear equation of one variable and ratio for seventh graders, and frequency distribution with graph and absolute value of complex number and complex number in polar form for eleventh graders.

The follows are details of patterns in teaching and examples of technology integration in teaching the target contents which the four pre-service teacher participants integrated in their classes for indicating the four pre-service teachers' levels of technology integration used in their teaching. To differentiate the four pre-service teachers, they are labeled with pseudonyms using $\mathrm{A}, \mathrm{B}, \mathrm{C}$, and $\mathrm{D}$ respectively.

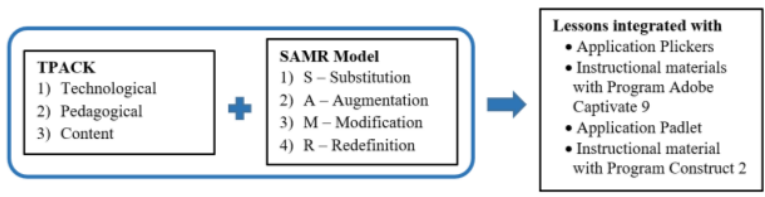

Figure 3. The pattern in teaching linear equation of one variable

As shown in Figure 3, the pre-service teacher A taught the content of linear equation of one variable for seventh graders. The lesson plans were integrated with various applications and programs such as Plickers for checking class attendance, Adobe Captivate 9 for creating instructional materials of the content, Padlet for encouraging expression of opinions or supporting question and answer session during the classes and homework submission as well as Construct 2 program for inventing a new game as a new instructional material on linear equation of one variable for an effective learning in this concept. The students can play the created games to practice their skills after learning the target content. The examples of the pre-service teacher A's technology integration in her class are presented in Figure 4.

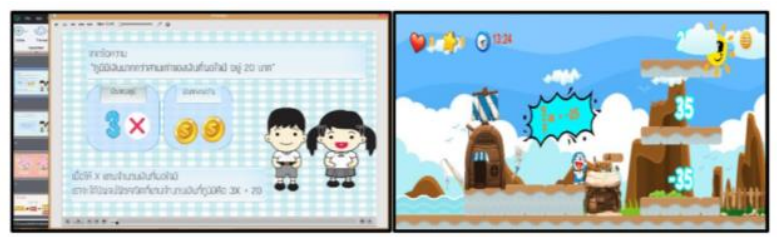

Figure 4. Examples of technology integration in teaching linear equation of one variable

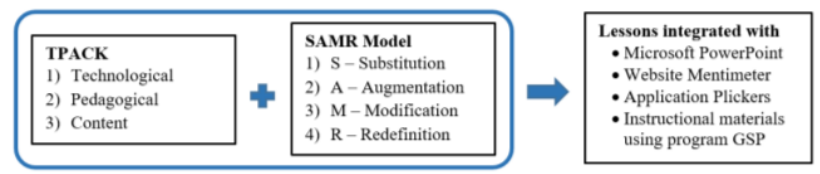

Figure 5. The pattern in teaching ratio

The pre-service teacher B taught the content of ratio for seventh graders as presented in Figure 5. She used Microsoft PowerPoint to explain the target content. Also, she integrated question board from website Mentimeter for her students to show their opinions or ask questions during the class. The application Plickers was used to check class attendance and to take pretest and posttest on the learning content. The program that the pre-service teacher B used in constructing new instructional materials for an effective learning the concept of ratio was the Geometer's Sketchpad program. The examples of technology integration used in the pre-service teacher B's class are demonstrated in Figure 6.

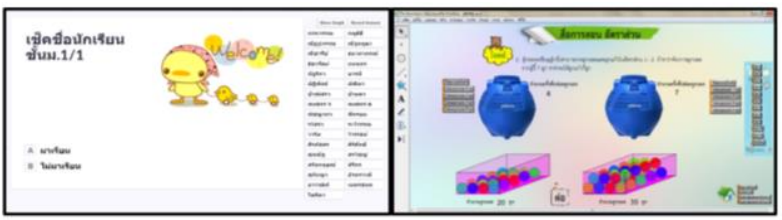

Figure 6. Examples of technology integration in teaching ratio

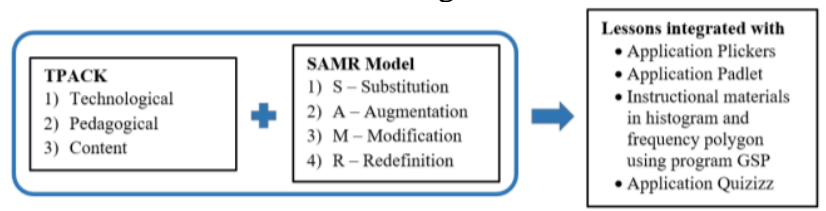

Figure 7. The pattern in teaching frequency distribution with graph

As illustrated in Figure 7, the pre-service teacher $\mathrm{C}$ taught the content of frequency distribution with graph for eleventh graders. Similar to the pre-service teachers A and B, she used application Plickers for checking class attendance and providing pretest and posttest on the target content. Also, the application Padlet was applied in the class to support opinion expression among the students or raising questions 
during the class and homework submission. Moreover, the Geometer's Sketchpad program was used to create new instructional materials on frequency distribution with graph using histogram and frequency polygon for more effective learning in this concept. Other than that, the pre-service teacher C employed the application Quizizz to summarize learning content and to promote the students in practicing the relevant skills by answering questions on cell phone. Figure 8 shows the examples of technology integration in the pre-service teacher C's class.

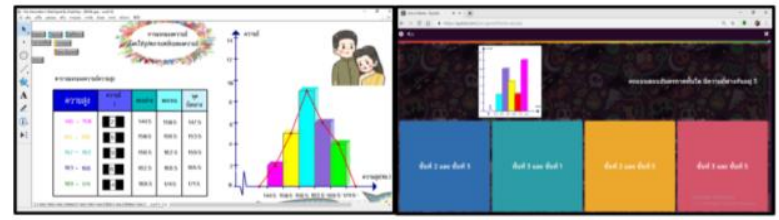

Figure 8. Examples of technology integration in teaching frequency distribution with graph

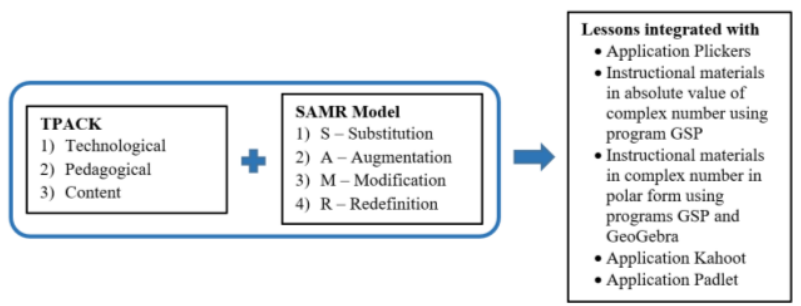

Figure 9. The pattern in teaching absolute value of complex number and complex number

in polar form

As displayed in Figure 9, the pre-service teacher D taught the content of absolute value of complex number and complex number in polar form for eleventh graders. During the intervention, she also used application Plickers for checking her students' attendance and measuring the students' understanding of the target content using pretest and posttest. It is in line with the pre-service teachers B and $\mathrm{C}$, she implemented the Geometer's Sketchpad program to create new instructional materials on absolute value of complex number and complex number in polar form. Besides that, she used Geogebra and the Geometer's Sketchpad program to construct new instructional materials for more effective learning in complex number in polar form. Two applications which the pre-service teacher D integrated in her class were Kahoot for posting questions and Padlet for question and answer session and homework submission.

The examples of technology integration used by the preservice teacher D are shown in Figure 10.

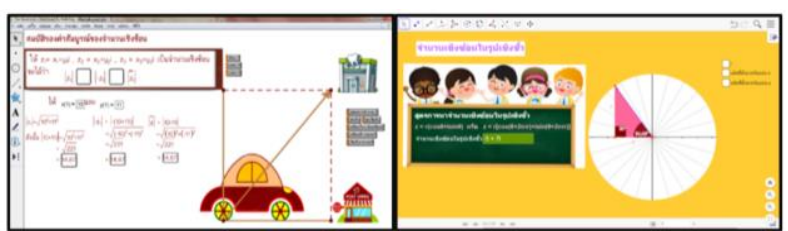

Figure 10. Examples of technology integration in teaching absolute value of complex number and complex number in polar form

As evidences, pre-service teachers' usage of technology in their teaching indicated that the four pre-service teachers applied the concept of TPACK and their levels of technology integration based on SAMR Model were at level four which considers the highest level. This shows that they used technology to compensate the tools that they previously used. The use of technology in their classes could enhance the effectiveness in teaching practice. Also, their usage in technology can be useful in designing new teaching to fit the integrated technology for creating new learning as well as new and different teaching method.

\section{Part Two (Quantitative results)}

Students' achievement, Students' learning retention, and their satisfaction levels towards learning.

Table 1. The students' achievement

\begin{tabular}{|c|c|c|c|c|c|c|c|}
\hline Contents & Tests & $\begin{array}{l}\text { Number of } \\
\text { Students }\end{array}$ & Mean & SD & $\mathbf{t}$ & df & Sig. \\
\hline $\begin{array}{l}\text { Linear equation of one } \\
\text { variable ( } 7^{\text {th }} \text { grade) }\end{array}$ & $\begin{array}{l}\text { pretest } \\
\text { posttest }\end{array}$ & $\begin{array}{l}30 \\
30\end{array}$ & $\begin{array}{c}4.47 \\
14.57\end{array}$ & $\begin{array}{l}2.42 \\
2.49\end{array}$ & -10.10 & 29 & 0.000 \\
\hline Ratio ( $7^{\text {th }}$ grade) & $\begin{array}{l}\text { pretest } \\
\text { posttest }\end{array}$ & $\begin{array}{l}32 \\
32\end{array}$ & $\begin{array}{c}9.28 \\
15.50\end{array}$ & $\begin{array}{l}2.49 \\
2.48\end{array}$ & -14.54 & 31 & 0.002 \\
\hline $\begin{array}{l}\text { Frequency distribution with } \\
\text { graph }\left(11^{\text {th }} \text { grade }\right)\end{array}$ & $\begin{array}{l}\text { pretest } \\
\text { posttest }\end{array}$ & $\begin{array}{l}28 \\
28\end{array}$ & $\begin{array}{c}7.00 \\
11.82\end{array}$ & $\begin{array}{l}2.78 \\
1.93\end{array}$ & -10.68 & 27 & 0.000 \\
\hline $\begin{array}{l}\text { Absolute value of complex } \\
\text { number and complex number } \\
\text { in polar form }\left(11^{\text {th }} \text { grade }\right)\end{array}$ & $\begin{array}{l}\text { pretest } \\
\text { posttest }\end{array}$ & $\begin{array}{l}27 \\
27\end{array}$ & $\begin{array}{c}5.70 \\
14.11\end{array}$ & $\begin{array}{l}1.94 \\
2.49\end{array}$ & -21.00 & 26 & 0.000 \\
\hline
\end{tabular}

The findings in Table 1 showed that posttest mean score of the students who studied each mathematics content based on TPACK and SAMR Model was significantly greater than their pretest mean scores at the significant level of 0.05 in all target contents. For example, the seventh-grade students' posttest mean scores who learned linear equation of one variable $(M=14.57, \quad S D=2.49)$, and ratio $(M=15.50$, $\mathrm{SD}=2.48$ ) were significantly greater than pretest mean scores $(\mathrm{M}=4.47, \quad \mathrm{SD}=2.42$ and $\mathrm{M}=9.28, \quad \mathrm{SD}=2.49)$; $\mathrm{t}(29)=-10.10, p<0.05$ and $\mathrm{t}(31)=-14.54, p<0.05$ respectively. Also, the eleventh-grade students' posttest mean scores who learned frequency distribution with graph $(\mathrm{M}=11.82, \mathrm{SD}=1.93)$ and absolute value of complex number and complex number in polar form $(M=14.11, S D=2.49)$ were significantly greater than pretest mean scores $(\mathrm{M}=7.00$, $\mathrm{SD}=2.78$ and $\mathrm{M}=5.70, \mathrm{SD}=1.94)$;

$\mathrm{t}(27)=$ 
$10.68, p<0.05$ and $\mathrm{t}(26)=-21.00, p<0.05$ respectively. Therefore, the results showed that the use of lesson plans based on TPACK and SAMR Model was effective in teaching the four different contents to the students.

Table 2. The students' learning retention

\begin{tabular}{|c|c|c|c|c|c|c|c|}
\hline Contents & Tests & $\begin{array}{c}\text { Number of } \\
\text { Students }\end{array}$ & Mean & SD & $\mathbf{t}$ & df & Sig. \\
\hline \multirow{2}{*}{$\begin{array}{l}\text { Linear equation of one } \\
\text { variable ( } 7^{\text {th }} \text { grade) }\end{array}$} & posttest & 30 & 14.57 & 2.49 & \multirow{2}{*}{1.06} & \multirow{2}{*}{29} & \multirow{2}{*}{0.291} \\
\hline & delay posttest & 30 & 14.13 & 2.33 & & & \\
\hline \multirow{2}{*}{ Ratio ( $7^{\text {th }}$ grade) } & posttest & 32 & 15.50 & 2.48 & \multirow{2}{*}{-0.88} & \multirow{2}{*}{31} & \multirow{2}{*}{0.385} \\
\hline & delay posttest & 32 & 16.03 & 1.80 & & & \\
\hline \multirow{2}{*}{$\begin{array}{l}\text { Frequency distribution with } \\
\text { graph }\left(11^{\text {th }} \text { grade }\right)\end{array}$} & posttest & 28 & 11.82 & 1.93 & \multirow[b]{2}{*}{1.24} & \multirow{2}{*}{27} & \multirow[b]{2}{*}{0.227} \\
\hline & delay posttest & 28 & 11.39 & 1.23 & & & \\
\hline \multirow{2}{*}{$\begin{array}{l}\text { Absolute value of complex } \\
\text { number and complex number } \\
\text { in polar form }\left(11^{\text {th }} \text { grade }\right)\end{array}$} & posttest & 27 & 14.11 & 2.49 & \multirow{2}{*}{1.76} & \multirow{2}{*}{26} & \multirow{2}{*}{0.091} \\
\hline & delay posttest & 27 & 13.26 & 1.83 & & & \\
\hline
\end{tabular}

The results as shown in Table 2 indicated that delay posttest mean scores of the students who studied different mathematics contents based on TPACK and SMAR Model had no significant different from their posttest mean scores at the significant level of 0.05 . For instance, the seventhgrade students' delay posttest mean scores who learned linear equation of one variable $(\mathrm{M}=14.13, \mathrm{SD}=2.33)$, and ratio $(M=16.03, S D=1.80)$ had no significant different from posttest mean scores $(\mathrm{M}=14.57, \mathrm{SD}=2.49$ and $\mathrm{M}=15.50$, $\mathrm{SD}=2.48) ; \quad \mathrm{t}(29)=1.06, p>0.05$ and $\mathrm{t}(31)=-0.88$, $p>0.05$ respectively. In addition, the eleventh-grade students' delay posttest mean scores who learned frequency distribution with graph $(\mathrm{M}=11.39, \mathrm{SD}=1.23)$ and absolute value of complex number and complex number in polar form $(\mathrm{M}=13.26, \mathrm{SD}=1.83)$ had no significant different from posttest mean scores $(\mathrm{M}=11.82, \mathrm{SD}=1.93$ and $\mathrm{M}=14.11$, $\mathrm{SD}=2.49) ; \mathrm{t}(27)=1.24, p>0.05$ and $\mathrm{t}(26)=1.76$, $p>0.05$ respectively. Such the reported findings, it was evident that the students had learning retention after they studied the four different mathematics contents based on the concepts of TPACK and SAMR Model. Interestingly, the eleventh-grade student' delay posttest mean score in teaching and learning the concept of ratio was greater than that posttest mean score. Hence, it can be suggested that teaching and learning with technology integration based on TPACK and SAMR Model was an effective teaching method for learning ratio for the eleventh graders

Table 3. The students' levels of satisfaction towards learning

\begin{tabular}{|c|c|c|c|c|c|c|c|c|}
\hline \multirow[t]{2}{*}{ Aspects and Items } & \multicolumn{2}{|c|}{$\begin{array}{c}\text { Linear equation of } \\
\text { one variable } \\
\mathbf{N}=\mathbf{3 0}\end{array}$} & \multicolumn{2}{|c|}{$\begin{array}{l}\text { Ratio } \\
\mathbf{N}=32\end{array}$} & \multicolumn{2}{|c|}{$\begin{array}{c}\text { Frequency } \\
\text { distribution with } \\
\text { graph } \\
\mathbf{N}=\mathbf{2 8}\end{array}$} & \multicolumn{2}{|c|}{$\begin{array}{l}\text { Absolute value of } \\
\text { complex number } \\
\text { and complex } \\
\text { number in polar } \\
\text { form } \\
\mathrm{N}=27\end{array}$} \\
\hline & Mean & SD & Mean & SD & Mean & SD & Mean & SD \\
\hline \multicolumn{9}{|l|}{ Content and Teaching } \\
\hline $\begin{array}{l}\text { 1. Clarity in identifying } \\
\text { outline in teaching. }\end{array}$ & 4.69 & 0.61 & 4.44 & 0.56 & 4.68 & 0.61 & 4.63 & 0.49 \\
\hline $\begin{array}{l}\text { 2. Clarity of learning } \\
\text { objectives. }\end{array}$ & 4.59 & 0.63 & 4.72 & 0.46 & 4.57 & 0.63 & 4.48 & 0.58 \\
\hline $\begin{array}{l}\text { 3. Clarity in assessment } \\
\text { and measurement in } \\
\text { learning. }\end{array}$ & 4.60 & 0.60 & 4.47 & 0.67 & 4.54 & 0.64 & 4.37 & 0.69 \\
\hline
\end{tabular}


Table 3. (Continued)

\begin{tabular}{|c|c|c|c|c|c|c|c|c|}
\hline \multirow[t]{2}{*}{ Aspects and Items } & \multicolumn{2}{|c|}{$\begin{array}{c}\text { Linear equation of } \\
\text { one variable } \\
\mathbf{N}=\mathbf{3 0}\end{array}$} & \multicolumn{2}{|c|}{$\begin{array}{l}\text { Ratio } \\
\mathrm{N}=32\end{array}$} & \multicolumn{2}{|c|}{$\begin{array}{c}\text { Frequency } \\
\text { distribution with } \\
\text { graph } \\
\mathbf{N}=\mathbf{2 8}\end{array}$} & \multicolumn{2}{|c|}{$\begin{array}{l}\text { Absolute value of } \\
\text { complex number } \\
\text { and complex } \\
\text { number in polar } \\
\text { form } \\
\mathbf{N}=27\end{array}$} \\
\hline & Mean & SD & Mean & SD & Mean & SD & Mean & SD \\
\hline $\begin{array}{l}\text { 4. Completion of content and } \\
\text { consistency with the current } \\
\text { curriculum. }\end{array}$ & 4.64 & 0.59 & 4.75 & 0.44 & 4.68 & 0.61 & 4.26 & 0.71 \\
\hline $\begin{array}{l}\text { 5. Teaching supports } \\
\text { student's analytical thinking. }\end{array}$ & 4.59 & 0.58 & 4.63 & 0.55 & 4.79 & 0.57 & 4.44 & 0.58 \\
\hline $\begin{array}{l}\text { 6. Teaching techniques } \\
\text { stimulate students' learning. }\end{array}$ & 4.73 & 0.58 & 4.59 & 0.50 & 4.68 & 0.61 & 4.44 & 0.58 \\
\hline $\begin{array}{l}\text { 7. Explanation and examples } \\
\text { are interesting and clear. }\end{array}$ & 4.65 & 0.62 & 4.75 & 0.57 & 4.71 & 0.60 & 4.48 & 0.64 \\
\hline $\begin{array}{l}\text { 8. Knowledge and } \\
\text { understanding from learning. }\end{array}$ & 4.74 & 0.63 & 4.59 & 0.56 & 4.54 & 0.69 & 4.48 & 0.70 \\
\hline \multicolumn{9}{|c|}{ Technology Integration in Teaching and Learning } \\
\hline $\begin{array}{l}\text { 1. Instruction and } \\
\text { knowledge are given for } \\
\text { understanding of } \\
\text { technology integration in } \\
\text { teaching and learning. }\end{array}$ & 4.62 & 0.67 & 4.47 & 0.57 & 4.54 & 0.69 & 4.63 & 0.56 \\
\hline $\begin{array}{l}\text { 2. Students can understand } \\
\text { and review learning } \\
\text { content by themselves. }\end{array}$ & 4.71 & 0.71 & 4.50 & 0.57 & 4.54 & 0.69 & 4.52 & 0.51 \\
\hline $\begin{array}{l}\text { 3. Activities in class are } \\
\text { varied and focus on } \\
\text { student-center. }\end{array}$ & 4.61 & 0.74 & 4.50 & 0.51 & 4.50 & 0.75 & 4.67 & 0.48 \\
\hline $\begin{array}{l}\text { 4. Activities in teaching } \\
\text { and learning are interesting } \\
\text { and fun. }\end{array}$ & 4.68 & 0.65 & 4.59 & 0.56 & 4.64 & 0.68 & 4.59 & 0.50 \\
\hline $\begin{array}{l}\text { 5. Teaching and learning } \\
\text { with technology } \\
\text { integration can enhance } \\
\text { students' understanding of } \\
\text { learning content in class. }\end{array}$ & 4.57 & 0.66 & 4.75 & 0.51 & 4.68 & 0.67 & 4.59 & 0.57 \\
\hline $\begin{array}{l}\text { 6. Assessment and } \\
\text { evaluation of learning } \\
\text { outcome with the support } \\
\text { of technology are suitable. }\end{array}$ & 4.69 & 0.61 & 4.72 & 0.46 & 4.57 & 0.69 & 4.37 & 0.69 \\
\hline Overall & 4.65 & 0.63 & 4.60 & 0.53 & 4.62 & 0.65 & 4.50 & 0.59 \\
\hline
\end{tabular}

As displayed in Table 3, the results of levels of satisfaction towards learning in the four target contents based on TPACK and SAMR Model showed that the students satisfied with the integrated teaching at a high level in both content and teaching aspect as well as technology integration in teaching and learning aspect. Also, the students showed a high level of satisfaction in all items under the two aspects. The overall satisfaction level of the students in the learning contents of linear equation of one variable, ratio, frequency distribution with graph, and absolute value of complex number and complex number in polar form was $4.65(\mathrm{SD}=0.63), 4.60 \quad(\mathrm{SD}=0.53), 4.62$ $(\mathrm{SD}=0.65)$ and $4.50(\mathrm{SD}=0.59)$ respectively.

\section{Discussions}

The research findings in the present study showed that the use of learning community integrating with lesson study enabled the pre-service teachers to come up with lessons for effective teaching in mathematics with the basis in technology integration. This is due to learning community and lesson study facilitated the pre-service teachers to exchange and learn cooperatively. They could exchange knowledge about technology integration in classroom teaching. Moreover, they helped each other to reflect their teaching practice and providing constructive feedback. The four pre-service teacher participants worked together to develop teaching and learning of mathematics which focused on the integration of technology for effective learning. The activities undertaken are consistent with the notion of learning community and lesson study which postulate that community is constructed for exchanging and learning general academic topics under interests with the aim of teaching and learning. Other than that, this also promotes development of knowledge, skills, attitudes through learning exchange, cooperative learning, and supports (Chang et al., 2010). This suggestion is in line with 
Chang et al.'s (2017) claim stating that a group of individuals in learning community addresses problems or their needs that they are interested in working together for better development. In the present study, the pre-service teachers showed their teaching patterns that indicated levels of technology integration which fit their teaching practice. Their development in teaching brings sequential teaching in integrating technology to organize teaching and learning and that can enhance their learning experience. The transformation of their learning in reference to levels of technology integration in SAMR Model was at the highest level (i.e., level four); R-Redefinition which refers to an integration of technology in offering new learning opportunities and different teaching methods. This study highlighted that the pre-service teachers' level of technology integration in teaching of different contents in mathematics based on TPACK and SAMR Model could improve the students' achievement and strengthen their learning retention. Apart from that, the students were greatly satisfactory with their learning experience with the integrated teaching because the use of technology integration in classroom corresponds with learners' learning in today education. What is more, the integration of technology makes classroom learning more interesting as supported by Goos (2014) which concurred that teaching with technology integration is effective and attractive to learners.

\section{Conclusion}

The results of the present study are beneficial for teachers and students. This study suggests that the use of learning community integrating with lesson study in school can create the process in sharing and learning exchange which leads to development of teaching and learning with the concepts of TPACK and SAMR Model. This integrated teaching with the teaching patterns which integrated different types of technology in apply for effective teaching and learning can enhance students' mathematics achievement. Moreover, this research points to the need of relevant courses with technology integration in the universities' teaching of mathematics education programs such as a course in technology for mathematics teacher. This offer encourages student teachers' learning about technology such as software for general teaching and mathematics teaching. The support in this perspective not only helps them to be familiar with integration of technology in teaching and makes an awareness in benefits of technology integration, but also promotes them in designing effective lessons for authentic teaching practices. The contribution in this study is crucial for providing directions to improve mathematics achievement and other subjects in future education.

\section{Acknowledgement}

The researcher would like to thank Yala Rajabhat University for granting funding support in conducting this research for enhancing pre-service teachers' teaching practice and developing effective mathematics teaching.

\section{References}

[1] Adulyasas, L. (2017). Measuring and factors influencing mathematics teachers' technological pedagogical and content knowledge (TPACK) in three southernmost provinces,
Thailand. SCOPUS Indexed AIP Conference Proceedings of the 4th International Conference on Research, Implementation and Education of Mathematics and Science, 1868(1), 0500321-050032-7.

[2] Chang, S. J., Wang C. C., \& Feng, L. Y. (2010). Teacher professional learning communities for elementary and secondary schools. Teachers' chamber, 169, 20-26.

[3] Chang, Y. F., Hsu, C. L., \& Ciou, P. S. (2017). Examining the use of learning communities to improve pre-service teachers' technological pedagogical content knowledge. International Journal of Learning and Teaching, 3(2), 136-143.

[4] Dinsmore, J., \& Wenger, K. (2006). Relationships in preservice teacher preparation: From cohorts to communities. Teacher Education Quarterly, 33(1), 57-74.

[5] Erdogan, A., \& Sahin, I. (2010). Relationship between math teacher candidates' Technological Pedagogical and Content Knowledge (TPACK) and achievement levels. ProcediaSocial and Behavioral Sciences, 2(2), 2707-2711. doi: 10.1016/j.sbspro.2010.03.400

[6] Goos, M. (2014). Technology integration in secondary school mathematics: The development of teachers' professional identities. In A. Clark-Wilson, O. Robutti, \& N. Sinclair (Eds), The Mathematics Teacher in the Digital Era (pp. 139-161). Dordrecht: Springer.

[7] Inprasitha, M. (2010). One feature of adaptive lesson study in Thailand: Designing learning unit. Paper presented at the $45^{\text {th }}$ National Meeting of Mathematics Education, Korea.

[8] Jimoyiannis, A. (2010). Designing and implementing an integrated technological pedagogical science knowledge framework for science teacher professional development. Computer \& Education, 55(3), 1259-1269.

[9] Kimberly, A., Lawless, K., \& Pellegrino, J. W. (2007). Professional development in integrating technology into teaching and learning: Knowns, unknowns, and ways to pursue better questions and answers. Review of Educational Research, 77(4), 575-614. doi:10.3102/ 0034654307309921

[10] Mishra, P., \& Koehler, M. J. (2006). Technological pedagogical content knowledge: A framework for teacher knowledge. Teachers College Record, 108(6), 1017-1054.

[11] Mishra, P., \& Koehler, M. J. (2009). Too cool for school? No way! Using the TPACK framework: You can have your hot tools and teach with them, too. Learning \& Leading with Technology, 36(7), 14-18.

[12] Niess, M. L. (2006). Guest Editorial: Preparing teachers to teach mathematics with technology. Contemporary Issues in Technology and Teacher Education, 6(2), 195-203.

[13] Norton, S., McRobbie, C. J., \& Cooper, T. J. (2000). Exploring secondary mathematics teachers' reasons for not using computers in their teaching: Five case studies. Journal of Research on Computing in Education, 33(1), 87-109. doi: 10.1080/08886504.2000. 10782302

[14] Pelgrum, W. (2001). Obstacles to the integration of ICT in education: results from a worldwide educational assessment. Computers and Education, 37(2), 163-178. doi: 10.1016/S0360-1315(01)00045-8

[15] Puentedura, R. (2015). The SAMR ladder: Questions and transitions. Retrieved April 17, 2020, from http://www.hippasus.com/rrpweblog/archives/2013/10/26/SA MRLadder

[16] Shamburg, C. (2004). Conditions that inhibit the integration of technology for urban early childhood teachers. Information Technology in Childhood Education Annual, 2004(1), 227244.

[17] Srisawasdi, N. (2012). The role of TPACK in physics classroom: case studies of preservice physics teachers. Procedia - Social and Behavioral Sciences, 46, 3235-3243. doi:10.1016/ j.sbspro.2012.06.043 